\title{
The language of the church: Westminster in review
}

\author{
W. John Carswell
}

At the General Assembly in 2018, ${ }^{1}$ I followed with keen interest the debate concerning the Overture from Peebles and Melrose Presbytery regarding the ongoing status of the Westminster Confession as subordinate standard of the Church of Scotland and was pleased to see the Overture referred to the Theological Forum. There were many who spoke out against the Overture and objections seemed to fall into one of two categories. The first of which was based on the recollection of the painful and protracted debates on the question of homosexual practice in the Church of Scotland, with the implication that the circular and dispiriting arguments over the authority of scripture would simply be revived under a different guise. The second, in light of the church's desire to focus its energy on the urgent need to address potentially terminal decline, suggested that the pursuit of such esoteric questions as the role of our subordinate standards would simply be a waste of energy and intellectual resources. The objection implied that such an agenda would be better suited to times of peace and prosperity when the church benefited from leisure sufficient to investigate arcane matters. In this paper I will argue that instead of serving as objections to such a study, they ought to serve instead as reasons for such a study.

The debate ran long and, while I stood to offer my tuppence worth, the Moderator, sensing that the will of the Assembly had tipped in favour of the Overture, encouraged the Assembly to bring debate to a close. I was poised at the microphone but agreed that further discussion was unnecessary to bolster the case further, which it turns out, was correct. Delegates will recall that the debate highlighted the PC(USA)'s Book of Confessions as an example of what the Church of Scotland's own confessional standards might look like in the future. It occurred to me, and perhaps to others, that the easiest way forward might be to use 
the Book of Confessions as a model for the development of our own collection of confessions in the Church of Scotland. It would certainly present a good beginning to a discussion, but such a move could easily defeat the purpose of the study and render any such version of the book a mere side-show to the main event of church renewal. It would miss the chance to become a doctrinal cornerstone of genuine and lasting renewal in the church. The process, agonising though it may be, is essential and formative, and skipping it would lead to a death of irrelevancy, proving right the objections that such a study would be a waste of time and energy. It was naturally disappointing to miss the chance to speak to the Overture but given that such a project may take some years to complete, time remains on my side to make a point.

I was raised in the PC(USA), trained at a PC(USA) seminary and served 12 years as a PC(USA) minister before translating to the Church of Scotland in 2008. While I do not profess to be an expert on the Book of Confessions, I am nonetheless familiar with its practical uses in teaching and in worship. Traditional PC(USA) worship invariably includes an Affirmation of Faith, usually following the sermon and most often taking the form of the Apostles' Creed, which allows the congregation to stand and respond to the proclamation of the Word with a hearty 'Amen' and a united voice of concurrence that ties it to the 'communion of saints'. Weekly recitation of the Creed serves as a reminder that the Church extends far beyond the four walls of the local congregation and in most cases is recited from memory. This slot in worship is however easily filled by using the Nicene Creed, or a portion of the Westminster Confession, or the Barmen Declaration, or the Confession of 1967, or the Brief Statement of Faith as a way of knitting the minister's sermon and the Word proclaimed to an historic aspect of church doctrine. Additionally, the Book of Confessions is carefully indexed making it very useful for researching specific aspects of doctrine; questions such as pouring versus sprinkling in baptism, the substance of Christ, sincerity in prayer, sexual relations, the development of weapons or the singing of lascivious songs ${ }^{2}$ are there for the picking, enabling a minister to tailor his/her teaching to meet specific, relevant and timely answers to the church's more vexing questions. The Book of Confessions remains a subordinate standard and so lacks the ecclesial authority of, for example, the 
Catechism of the Catholic Church. It is intended to serve as a guide, but it is nonetheless illuminating and thought-provoking and helpful for generating reflection on matters of faith and life.

The fact that it is timely and relevant is no accident for each of the confessions was written and chosen for inclusion in the Book precisely because it was timely and relevant. They are theological statements, true, but say as much about cultural history as they say about doctrinal history for each was written to address particular questions both within and without the church. The confessions are written with three audiences in mind: God, the church and the world. That is, they speak a word of praise and thanksgiving to God for God's self-revelation to the world and to the church; they speak to the church itself and clarify who the church is, what it believes and what it resolves to do; and lastly the confessions serve as the voice of the church and provide for the world 'a unified word that declares who they are and what they stand for and against.' ${ }^{3}$ None of the confessions were written during periods of leisure, peace or prosperity but rather in the midst of existential crisis within the church and cultural crisis without. They were not written as intellectual curios or idle speculations, but rather to enable the faithful to live as God called them to live during challenging, confusing and often desperate circumstances. The confessions were Barth's Nein! to the demands of the Nazi state (Barmen Declaration), the church's call to reconciliation (Confession of 1967), the church's 'yes' to the joy of reunification in 1983 (Brief Statement of Faith), and Knox's explication of God's providential care (The Scots Confession). Each of these answers were couched within a sometimes brief, sometimes lengthy, explication of the nuances of Christian faith and life. In other words, the confessions were an effort by the best theologians of the day to teach the church not only what to believe, but what to do and how to live faithfully. They were, in the best sense, sapiential, attempting to connect the knower with the Known. I will say more about this in what follows, but to summarise this introduction I believe the time is right to revaluate the role and function of the Westminster Confession and confessions generally in the Church of Scotland. When the subject was broached 40 years ago, the rumbling of church decline and cultural dissolution were audible to those who were listening, but the church was still large enough 
(complacent enough?) that such rumblings could be dismissed or ignored. Today, the church and the culture are virtually univocal in predicting ongoing and potentially terminal ecclesial decline. We need a clear statement about God addressed to ourselves and to our culture about who the church is, what it believes and what it resolves to do. In this paper then I will reflect on the role of doctrine with the aim of highlighting just how important a contemporary statement of faith is, or might be, to the church and to its members. I will do so within the framework provided by the PC(USA) considering who the church is, what it believes and what it resolves to do.

Alister McGrath ${ }^{4}$ very helpfully delineates four uses of doctrine that I will use as a framework for my own reflections, namely doctrine as social demarcator, as narrative, as interpreter of experience, and as truth statement. For the sake of space in this paper I will focus on McGrath's discussion of doctrine as social demarcator and as interpreter of experience, commending his other two categories to the reader as a further subject of interest. Thirdly, I will consider doctrine as sapience. Each of these categories helps the reader consider the 'who' and 'what' questions raised by the PC(USA).

\section{Doctrine as social demarcator}

McGrath argues that in order to be properly understood doctrine must be viewed within its wider historical context and that its function is derived as much for social reasons as for theological ones. Historically the development of doctrine is 'particularly evident in cases in which a religious group originates through rupture with an older grouping, ${ }^{5}$ Doctrine then becomes a tool for establishing a social demarcation between rival groups who might otherwise fall under the same ecclesiastical rubric. When social differentiation is of paramount importance doctrinal disputes come to the fore. However, McGrath continues that in the absence of potentially viable rivalries to the established church the move towards doctrinal standards is less compelling and that when the social distinction is no longer needed doctrine fades in importance. The tragic history of church division is marked over and again by doctrinal issues that rise to the surface to create or demarcate unique distinctions between rival groups. 
When the church is at war with itself, doctrine attempts to answer the questions of 'who the church is' and 'what it believes', but when there is relative harmony within the church, it cannot then forget that it is by its nature at war, or at least at odds with the culture. Faith sets the church apart from the culture, electing its members and adherents into the company of 'exiles' (1 Peter 1:1). The danger today is in making the assumption that the church has the prerogative to set the moral and spiritual agenda of the nation, just as it did 400 years ago, and that the doctrine of the church correspondingly becomes the doctrine of the nation. But, the problem with assuming doctrinal hegemony across the culture is that doctrine fades to the point of irrelevancy and the witness of the church becomes little more than an endorsement of cultural values. Raising concerns about the Church of Scotland as the 'national church', David Wright asked:

what if the kind of Christian faith credibly attributable to any majority of the population is credally vacuous, driven by sentiment more than conviction, humanitarian under at best a religious veneer - does the Church of Scotland have a duty to be representative of that religion of universal niceness, barely recognizable as "Christian faith"? ${ }^{6}$

In other words, when there are no 'viable rivalries to the established church' the temptation is to act 'as though the Church still enjoyed general acceptance'. ${ }^{7}$ But Wright argues, alongside Stuart Murray, ${ }^{8}$ that the church in Britain and Scotland is now a minority culture and will likely remain a minority for many decades so that it can no longer assume its credal convictions are synonymous with those of the culture. That is, in the secular culture of contemporary Scotland there are many 'viable rivalries to the established church', especially the growing rivalry of those who claim to practice 'no religion'. With less than $8 \%$ of the population attending worship on any given Sunday, ${ }^{9}$ the established church must of needs embrace a new status as a minority community that is socially distinctive within a secular, apathetic and occasionally hostile culture. Doctrine must be highlighted in the church as a means of articulating that social distinction. The Westminster Confession was written within a culture that was perhaps 
more amenable to the claims of Christianity, but its writers were no less clear that the practices of the church served to create a visible and existential line separating it from the surrounding culture. Any contemporary statement of faith must be even more aware of the need to maintain that line of social distinction, not so much as an effort to cut the church off from the surrounding culture, as to illuminate the fact that the church lives within a narrative that is distinctly different from the surrounding culture. It sings from a different sheet of music, marches to the beat of a different drummer, comes from a very different past and looks forwards to a very different future.

\section{Doctrine as interpretation of experience}

Doctrine as social demarcator answers 'who the church is', but doctrine as interpretation of experience enables the church to answer the question 'what it believes'. Believers must be gifted with the ability to 'give an account' (1 Peter 3:15) of their faith in a manner that is cogent, winsome and persuasive to those for whom Christianity is remote and unfamiliar, or whose experience of the church may have left them lukewarm or discouraged in faith. To say what it believes, the church needs words that are sensible not only within ecclesiastical circles, but without as well. A confession is, at least in part, an apology to a secular world, an explanation and defence of what is held to be precious and transformative about the Gospel. The difficulty with language is that it so often fails to convey what is encountered in the holy. Even attempting to articulate what is, for many, an inarticulate and supra-rational experience may seem to make less of what has transpired in their lives. But, language is essential to the church based as it is upon the living Word itself. The Gospel is a word to the world, and so words are vital, the sine qua non of proclamation. Doctrine has the capacity to provide the language necessary to navigate and articulate the experience of the holy. Again, McGrath:

Underlying the profundity of human experience and encounter lies an unresolved tension - the tension between the wish to express an experience in words, and the inability of words to capture the experience in its fullness. [...] It is threatened with a solipsism, 
in that unless an experience can be communicated to another, it remains trapped within the private experiential world of an individual. ${ }^{10}$

But, doctrine provides a descriptive framework within which an individual might put experience into words, perhaps not his/her own words but the borrowed words and the language of the church by which his/her experience of God might be made more sensible. A knowledge of doctrine enables an individual to explain to others what has happened to him/her and provides justification for taking further action in the form of participation in a believing community. Of course, there lies an inherent danger in attempting to express Christian experience in words in that language often 'flattens' or 'empties' experience of its evocative power and becomes utilitarian. Charles Taylor argues that 'the ordinary use of language in our age operates with it as though its only function were the instrumental one of designating already recognized elements'. ${ }^{11}$ Language does not lead to knowing, but merely describes what is already known by other means. Taylor however draws attention to the 'revelatory power of language' and suggests that language can be not only descriptive of experience, but constitutive of experience. Language alone cannot recreate or evoke Christian experience, but it can give shape to what transpires in experience. 'There are realities that are made manifest to us only in language, and especially poetic language. And it does so because it resonates with us; it strikes a chord in us. ${ }^{12}$ The words may take the form of poetry or song or even be conveyed wordlessly in artwork or dance or music or craft, but they are words nonetheless that have the power not only to make sense of what has been encountered but can become an 'event with performative force [...] open[ing] up contact, mak[ing] something manifest for the first time'. ${ }^{13}$ The words are not the experience in themselves, but nonetheless have the power to serve as signposts directing a sojourner to his/her own experience. Doctrine therefore has the potential to both articulate the experience of one person and to evoke and constitute the same experience for another, which is of course the pattern of extending faith from one person to the next. Doctrine has the capacity to serve the church in this manner, but equally it can deaden the experience of faith when 
it is portrayed as a rote exercise or as a law that requires subscription and conformity. When doctrine loses sight of its purpose as a means of expressing and constituting faith, when it becomes an end in itself it must of needs be revaluated by the church and if necessary, jettisoned, or perhaps more constructively, relegated to a place of lesser authority in the life of the church as an historic statement of faith. ${ }^{14}$

\section{Doctrine as sapience}

Doctrine as sapience attempts to answer the question 'what it resolves to do'. Christian behaviour, or uniquely Christian being, is a function of both knowledge and practice. Browning refers to this combination of lessons and practice as practical reason or phronesis, the ability to combine theory with practice:

The tradition of practical reason or practical wisdom has its origins in Aristotle's concept of phronesis. Jesus used the word phronesis in the Sermon on the Mount (Matt. 7:24) to refer to the 'wise' persons who listen to the message of Jesus and build their lives upon it. ${ }^{15}$

He relates that:

Since the Enlightenment, the modern experiment has been dedicated to the improvement of human life through the increase of objective scientific knowledge (theoria) that is then applied to the solution of human problems (technē).$^{16}$

There is no arguing that this 'experiment' has resulted in great 'improvement of human life', but his point is that something important has been lost along the way, especially when it comes to the practice of the Christian faith. Ellen Charry argues that the Enlightenment separation of knowledge into two parts raised a false dichotomy between knowledge gained by reason and analysis, and knowledge gained by experience, wisdom or revelation, consequently devaluing the second. Scientia is 'knowledge based on demonstrable 
and reproducible data ${ }^{17}$ but Charry describes the second as sapience and writes:

Sapience includes correct information about God but emphasizes attachment to that knowledge. Sapience is engaged knowledge that emotionally connects the knower to the known. ${ }^{18}$ [Italics mine]

In other words, knowledge or technical information about a subject serves only one half of its purpose. Charry argues that Christian knowledge was intended to lead to meaningful life in God, but argues:

Sapiential theology waned with modernity. Theology came to be thought of as the intellectual justification of the faith, apart from the practice of the Christian life. The wisdom of God has ceased to function in the church as the foundation of the good life. ${ }^{19}$ [Italics mine]

By this definition doctrine is purposeful only inasmuch as it creates or expresses a sense of unity between God and the individual enabling him/her to live a more faithful life. Doctrine ought to serve as the 'foundation of a good life' in the knowledge of God's love. Knowledge or doctrine for its own sake is something less than what it was intended for and without engaging the 'knower' more intimately with the 'Known' it fails in its essential function. Both Charry and Don Browning point to Hans-Georg Gadamer who illustrated the fallacy of the Enlightenment project when he introduced the idea that the supposedly objective observer brings a great deal of what he calls "prejudices and commitments, "fore-understandings" or "foreconcepts", to an experiment. ${ }^{20}$ In effect, the scientist cannot escape his/her own history, person and prejudices. According to Charry, Gadamer's thinking created an opening for the recovery of sapiential knowledge:

He recognized the relationship between the knower and the known, and, by implication, the responsibility of the interpreter to assist the reader in participating in that relationship. [...] the 
Enlightenment's hope of objectivity failed to admit [that] the modern notion of truth and knowledge, which excludes the knower from the knowledge, is unrealistic and too narrow to be genuinely useful. $^{21}$

In other words, the predispositions of the writer negate the possibility of presenting concepts in a purely objective way and the author must recognise a sense of responsibility for presenting his/her ideas in a way that enables the reader to connect the knowledge presented with the source of that knowledge or the subject that is known. This is especially pertinent for the theologian whose work it is to present what Charry calls 'the divine pedagogy':

Christian doctrines function pastorally when a theologian unearths the divine pedagogy in order to engage the reader or listener in considering that life with the triune God facilitates dignity and excellence. $^{22}$

The theologian cannot so distance him/herself from his/her work that $\mathrm{s} /$ he is emotionally detached from it. His/her history and personal experience invariably affect not only the content of what is being written but its intended consequence. Sapiential doctrine gathers together in one the mind and the heart of the writer as s/he attempts to convey in words the way in which s/he has made sense of a living faith. The writer can neither escape nor remain uninfluenced by his/ her own history and in gifting that to the reader through his/her words $\mathrm{s} / \mathrm{he}$ invites the reader to travel a similar journey into the heart of God. The writing and the reading of theological texts then become, as Charry argues, 'spiritual disciplines undertaken by those open to the inspiration of the Holy Spirit. ${ }^{23}$ The arguments against reviewing Westminster seem to have been based in an Enlightenment view of doctrine, scientia divorced from sapientia, knowledge separated from practice, and were perhaps justified in the fear that further doctrinal study and reflection might simply redirect energies better spent on the more immediate concern of church decline. But when viewed as a sapiential pursuit intended to enable contemporary believers to live 
out their Christian convictions in a secular culture it becomes a project of more practical use and one that, in the long term, may address church decline at its root by empowering the church not only to know the Christian faith, but to live it.

\section{Review}

The church today has an uneasy relationship with its doctrine. While few would suggest it is irrelevant or unimportant many struggle nonetheless to find its practical value. The church must ever be wary that its doctrine often becomes remote from its practice.

David Hamilton for example argues that 'The gap between what the theologians are saying and what the laity are seeing and hearing is alarmingly wide. Theology to many seems elitist and remote. ${ }^{24}$ If doctrine is to answer 'who' the church is, it must be emphasised in preaching and in teaching as a priority for those who profess to live as Christ's disciples. Quite simply, doctrine must be taught. Similarly, doctrine must be learned as the language of faith. The church cannot talk about God to itself, much less to the world, if it lacks the vocabulary that enables individual believers to say what they believe in a way that is cogent, winsome and sensible to themselves and to others. In reviewing the Westminster Confession, the church does well to ask whether its language has lost the capacity to serve as a credible means of expressing the substance of Christian faith and no longer resonates with the experience of the faithful.

The challenge with doctrinal statements is that no sooner are they written then they are out of date. They are of necessity grounded in unique cultures and undergirded by the peculiar ideologies of the writers. They are written to address particular concerns within the church and within the culture and, as these concerns often quickly pass from the public consciousness, the answers of yesterday's creeds no longer satisfy the contemporary reader; the questions themselves change and what was a concern of paramount importance quickly becomes a foregone conclusion upon which further speculation is redundant. Doctrine makes the general particular and creates the impression that its writers are attempting to consolidate and 
conform an idea or experience that is highly diffuse and by no means universal. In some respects, the formulation of doctrine curtails further discussion of a subject for which many remain indeterminate or confused or convinced of the opposite: 'Doctrinal formulations are seen as premature foreclosures of debates which, by their nature, ought to be declared permanently open. ${ }^{25}$ But then, so are pictures and snapshots in a family album. No sooner is the image cast then it ceases to portray present reality. But, as social media proves, pictures are vitally important and serve to express a feature(s) of one's identity that is deemed essential to the one posting the image. It is certainly not the whole story, but it is an important part of the story that is worth sharing with one's 'friends' public and private. A picture represents something, it is part of a story worth sharing with others and quickly garners an approving crowd of 'likes' ... or not. Of course, social media allows the one posting his/her image to frame it in such a way that it presents an idealised version of him/herself, but even that tells a story about the desires of the individual and what $\mathrm{s} / \mathrm{he}$ esteems as of highest value. A picture creates a history that bears directly on the present as a statement not only of who we were, but of who we are and who we would like to be. It is a collection of data, the sum total of which crafts a complex sense of oneself in the world and in relation to others. In like manner, a statement of faith is drafted not only as an expression of who the church is, but more aptly, as an expression of who the church yearns and strives to be; it states an idealised goal rather than a fait accompli. Confessions are of course vulnerable to the law of diminishing returns and with each new statement of faith inserted into the PC(USA)'s Book of Confessions one is left to wonder about the authority of the others. Do more confessions equate a more comprehensive expression of ecclesial identity, or do the multiplicity of voices reduce its witness to a cacophonous babble? The Book of Confessions is like a credal buffet from which one can 'cherry-pick' favourite notions that may or may not form a contiguous whole. Equally, one might dismiss them all as relics that have little if anything to offer the contemporary believer. But then, why take pictures?

The Church of Scotland exists within a framework of Reformed history very similar to that of the US and in the coming months 
(years?) it will have the prerogative to consider the worth not only of the Westminster Confession, but the many others that form a part of our doctrinal heritage. The church could follow the example of the PC(USA) and issue its own compendium, but as I suggested at the beginning of this paper, such a move would defeat the purpose of the remit and simply create a doctrinal museum piece. The Church of Scotland needs to do the hard work of establishing its own answers, expressed in a language that is sensible to ourselves and to our culture. Even more importantly, we must learn to listen to one another and to the world for the best questions; there is no point in labouring to answer the questions asked by former generations. One thing that can be said about a journey towards a fresh doctrinal statement(s) is that reviewing and rewriting doctrine can provide direction on a journey towards genuine renewal; the church's current crisis is an opportunity to discover, or perhaps recover and renew its sense of identity and purpose in the midst of profound cultural changes. If the church is to go on speaking about God to the church and to the world, answering the perennially important questions of who it is, what it believes and what it intends to do, it must learn to do so in a language commensurate with that of the contemporary era. Anything less would be a failure of speech.

\section{Notes}

1 Issues relating to the Westminster Confession have been raised over the years at the General Assembly of the Church of Scotland, most recently in 2018. Following an overture from the Presbytery of Melrose and Peebles, the Theological Forum was instructed to review the status of the Confession. (Ed.)

2 Westminster Confession, section XXX.3; Second Helvetic Confession, XI; Westminster Larger Catechism, Q. 185, 192; Confession of 1967, section II.A.4.d.; ibid., II.A.4.b; Larger Catechism, Q. 139.

3 Office of the General Assembly, Presbyterian Church (USA), The Constitution of the Presbyterian Church (USA). Part I: Book of 
Confessions (Louisville, Ky.: Office of the General Assembly, 1999), xiii.

4 Alister E. McGrath, The Genesis of Doctrine: A Study in the Foundation of Doctrinal Criticism (Grand Rapids, Mich.; Cambridge: Eerdmans, 1990), 35-80.

5 Ibid., 38.

6 David F. Wright, "The Kirk: National or Christian?", in The Realm of Reform: Presbyterianism and Calvinism in a Changing Scotland, ed. Robert D. Kernohan (Edinburgh: Handsel, 1999), 33.

7 Ibid., 34.

8 Stuart Murray, Church After Christendom (Milton Keynes: Paternoster, 2004), 25.

9 Brierly Consultancy, "The 2016 Scottish Church Census" http:// www.brierleyconsultancy.com/scottish-church-census/ (Accessed 29 May 2017)

10 McGrath, Genesis of Doctrine, 67.

11 Charles Taylor, A Secular Age (Cambridge, Mass.; London: Belknap Press of Harvard University Press, 2007), 758.

12 James K. A. Smith, How (Not) to Be Secular: Reading Charles Taylor (Grand Rapids, Mich.; Cambridge: Eerdmans, 2014), 136.

13 Taylor, A Secular Age, 758.

14 Roderick Pettigrew, "The Recent Debate in the Church of Scotland", in The Westminster Confession in the Church Today, ed. Alasdair I. C. Heron (Edinburgh: Saint Andrew Press, 1982), 73.

15 Don S. Browning, A Fundamental Practical Theology: Descriptive and Strategic Proposals (Minneapolis: Fortress Press, 1991), 10.

16 Ibid., 34.

17 https://www.merriam-webster.com/dictionary/scientia

18 Ellen T. Charry, By the Renewing of Your Minds: The Pastoral Function of Christian Doctrine (New York; Oxford: Oxford University Press, 1997), 4.

19 Ibid., 5.

20 Browning, Fundamental Practical Theology, 38. Cf. Hans-Georg Gadamer, Truth and Method (New York: Crossroad, 1982), 235, 261. 
21 Charry, By the Renewing of Your Minds, 17.

22 Ibid., 18.

23 Ibid., 21.

24 David S. M. Hamilton, Through the Waters: Baptism and the Christian Life (Edinburgh: T\&T Clark, 1990), 8.

25 McGrath, Genesis of Doctrine, 163. 